\title{
Valentina GERASIMENKO
}

Russia, Lomonosov Moscow State University, Economic Department gerasimenko@econ.msu.ru

\section{Marina OCHKOVSKAYA}

Russia, Lomonosov Moscow State University, Economic Department ochkovskaya@econ.msu.ru

\section{Maria RYBALKO}

Russia, Lomonosov Moscow State University, Economic Department rybalko@econ.msu.ru

\author{
Lomonosov Moscow State University \\ GSP-1, Leninskie Gory, Moscow, 119991, Russian Federation \\ +7 49593957 22, marketing@econ.msu.ru
}




\section{FACTORS AFFECTING A BRAND'S PERCEPTION IN RUSSIA}

This paper demonstrates the importance of a high perceived quality for brands and delves into ways for strengthening it, as well as examining the global trends which affect a consumers' decision, particularly in the Russia. Taking into account these trends, the authors study the factors behind a positive effect on the brands' perception in Russia and present ways to transform the high actual quality in the perceived one. The findings from different groups analyses carried out on female and young (students) consumers show the specific of global trends implementation in Russia. In addition, the analyses confirm the efficiency of ways for strengthening the perceived quality of brands.

Key words: Brand, brand reputation, brand's perception, actual quality, perceived quality, global trends, consumers

JEL codes: M31, M37

\section{Introduction and objective}

There are a lot of brands in the world, both global and local, some with long histories and others with rather young ones. Today, Russia is a huge market open for multinational companies and brands. Some brands like Coca-Cola, Tide, McDonald's and many others have already conquered the hearts of Russian consumers and it seems now that they are an indispensable part of our everyday life. Famous Italian brands such as Armani, Salvatore Ferragamo, Valentino also have a magical influence on the Russian customers.

Although famous worldwide brands such as Coca Cola and McDonald's came into the Russian market more than 20 years ago, there are still many global brands penetrating in Moscow and regions. It's very important, then, to know what really matters to the Russian consumers, what they really appreciate in products and services.

This paper examines factors and signals affecting a brand's perception in Russia and highlights some ways for the product's perceived quality support.

\section{Literature review}

There is no clear definition for the term "brand". As Jean-Noel Kapferer (2008) says, a brand is "one of the hottest points of disagreement between experts. Each expert comes up with his or her own definition, or nuance to the definition".

For example, Philip Kotler and Gary Armstrong (2008) defines a brand as "a name, term, sign symbol or a combination of these, that identifies the maker or seller of the product". But a brand is much more than just a name and logo.

J.-N. Kapferer (2008) writes that a "good name helps. One that is easily pronounceable around the world and spontaneously evokes desirable associations. But what really makes a name become a brand is the fact that this name commands trust, respect, passion and even engagement". So in Kapferer's opinion, a brand is not just a simple name "it is a name with the power to influence the market" (2008). 
Keller places a brand's definition as "a set of mental associations, held by the consumer, which add to the perceived value of a product or service" (2008). But a brand is not only about the consumers' side. Although Ogylvy said that "products are built in factories, brands are built in the mind", today it is critical to take into account the producer's side, the brand's creator.

David Aaker operates with two terms: brand image and brand identity. "Brand image is how a brand is perceived, brand identity is how the brand would like to be perceived" (2002). So brand identity is about the producer's side as brand image - consumer's.

Kapferer writes that "a brand is a shared desirable and exclusive idea embodied in products, services, places and/or expectations" (2008). For example, Kilian is a "perfume as an art" or German chocolate "Ritter Sport" which is "chocolate with a difference" with famous its slogan "Quadratisch. Praktisch. Gut". It's crucial that a brand's image and identity coincide with each other.

Brand deals with the perceived quality. The perceived quality is an important element in David Aaker's brand equity model. According to Aaker, perceived quality is even more pivotal than the actual quality for brands. He describes the perceived quality as "the customer's perception of the overall quality or superiority of a product or service with respect to its intended purpose, relative to its alternative" (1991). The "perceived quality" concept is rather complex. Actual quality and perceived quality is not the same. Achieving actual high quality, according to Aaker, is not enough. The high actual quality should be translated into high perceived quality. Consumers should believe in the product or service.

The perceived quality has a connection with the country of the brand's origin. Aaker, Keller and Kapferer all mention the role of the country of origins affects on perceived quality. For example, a label "Made in Italy" has a positive effect on a consumer's decisions about fashion brands, and "Made in France" has a similar affect for perfume, wine and also apparel.

Factors affecting a brand's perception can vary in different countries and are usually connected with global trends influencing the consumer's behavior. The global trends used in the paper are studied by global agencies Trendwatching (www.trendwatching.com) and TNS Russia (http://www.tns-global.ru). Also, some current tendencies affecting a consumer's decisions and marketing activities have been derived from the Harvard Business Review Magazine ("The 10 Trends You Have to Watch". Harvard Business Review, July-August 2009).

\section{Methods}

Qualitative and quantitative research was used during preparation of the paper. Survey and observation methods were utilized in our study for primary data collecting. While analyzing the secondary data, we used the method from particulars to generals and from the general to the special.

\section{Findings and discussion}

Russians have been captured by global brands since the beginning of 1990s, when the USSR collapsed. Coca Cola came into the Russian market in 1988. At that time Coca Cola was new and exciting alternative for Soviet customers. The small bottle of Coke was like a dream, a step to a new prosperous and American life style. Similarly, McDonald's, whose first Russian restaurant was opened 
on 31 January 1990, was met happily by a huge queue of people waiting for hours. At that time the term "brand" was new-fashioned and unusual for the Russian consumers, as well as the word "marketing", but today the situation has changed completely.

Today there are incomparably many more multinational brands in Russia than 20 years ago; consumers have become more sophisticated in their choices and international terms "brands" and "marketing" are no longer new in the Russian language. Global hypermarkets (as Auchan, Metro), supermarkets, boutiques have all appeared in Russia during the last 20 years, and have been forming the so called culture of consumerism.

Working on this paper we analyzed global trends affecting consumer behavior in the Russian context. Global trends in the local context are named as "glocal" in the article.

\section{"Glocal" trends influencing marketing tools}

The first global trend is population aging. The Russian population, as in Europe and the United States, is getting older and there is a big quantitative imbalance between working people and pensioners.

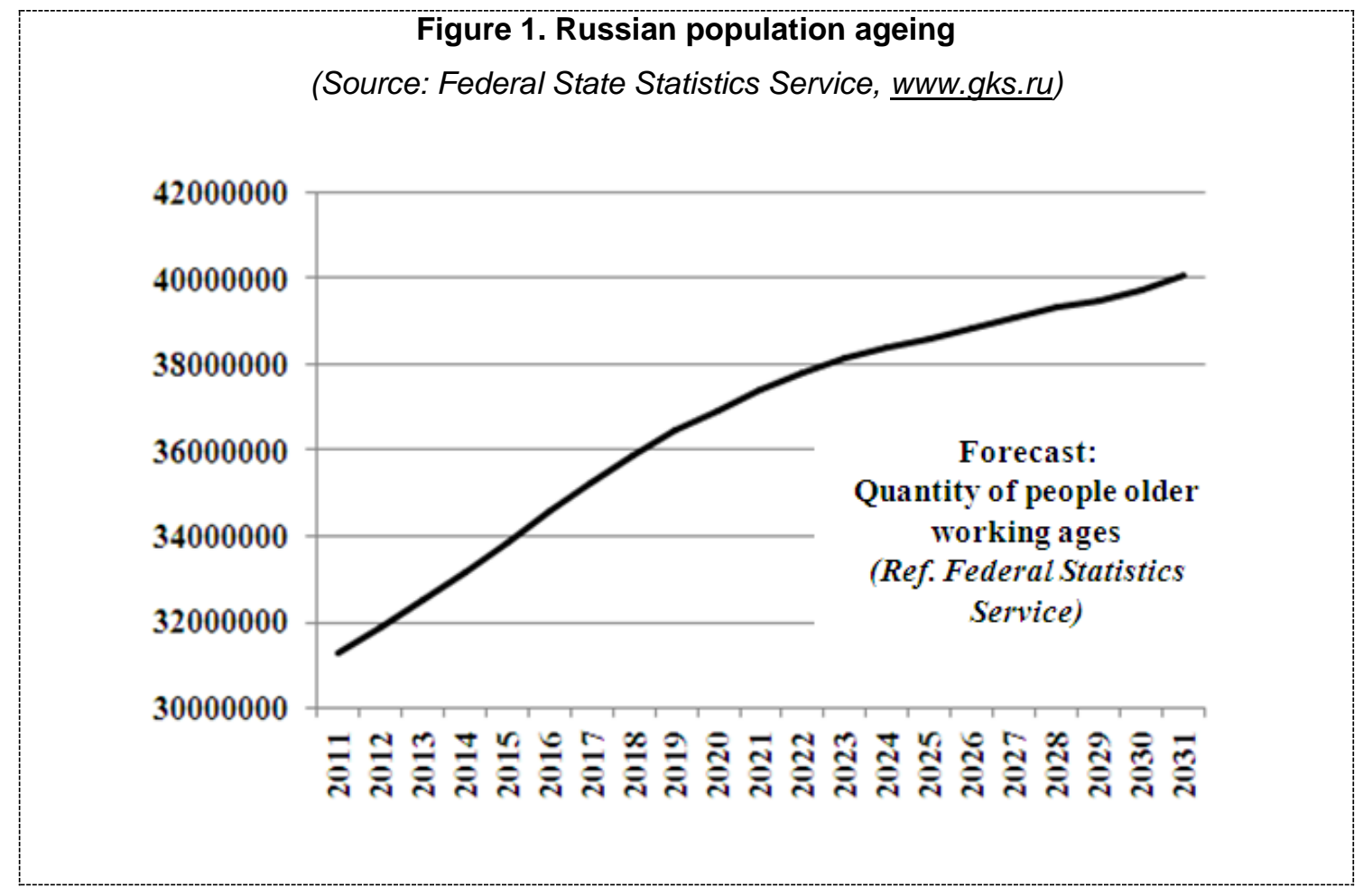

In Europe there are a wide variety of products for women over 65, ranging from special skin cares, hair care. Interestingly, in Russia, these same products are usually offered to women who are around $45-50$ years old. This can be explained by the limited paying capacity of Russian pensioners (the average pension in Russia in 2011 was about 210 Euros per month). Because of this, the majority of current pensioners in Russia are not susceptible nor open to brands.

The Harvard Business Review Magazine in 2009 mentioned the simplicity trend. This tendency has been beginning in 2008 and it is still continuing. This trend is about transforming complicated things into something simple and user-friendly. 
People in metropolises have no time for reading lengthy instructions and learning how to deal with complicated mechanisms. This trend can be illustrated with the figure 2:

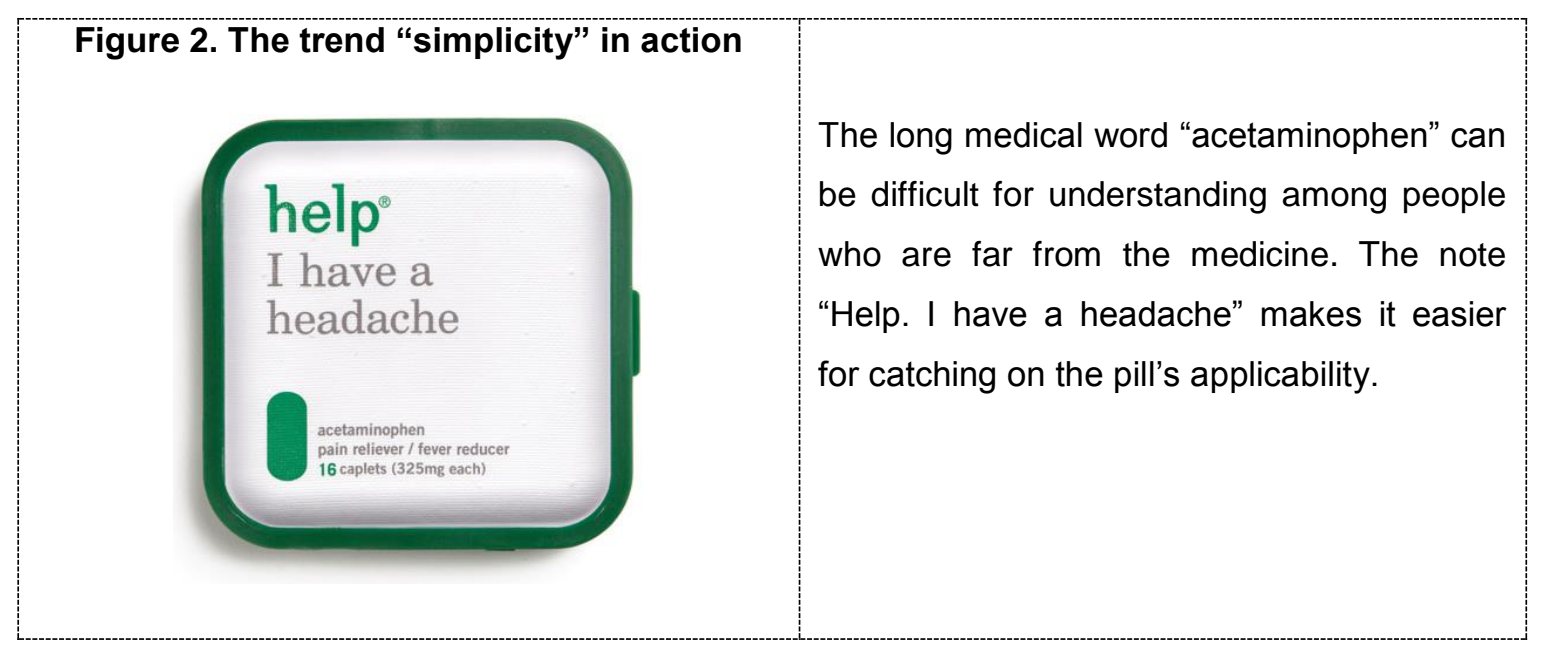

The third global trend we'd like to stress is eco-friendly tendency. Organic cosmetics, ones never tested on animals, are in high demand among European consumers. Although in Russia this tendency is not very strong yet, brands such as Body Shop and Lush, which never test their products on animals, are presented in Russia and people like these brands, but the motives for buying them are far from only ecological.

While working on this paper we researched the reasons Russians are buying Lush cosmetics. 100 loyal female consumers of Lush were surveyed on-line during May 2012 and were asked to indicate their primary reason for purchasing this brand. The consumers were asked to indicate the main cause for purchasing this brand. Three potential reasons were presented in the questionnaire:
1) Eco-friendliness
2) High quality and well-known brand
3) Atmosphere and good service in boutique.

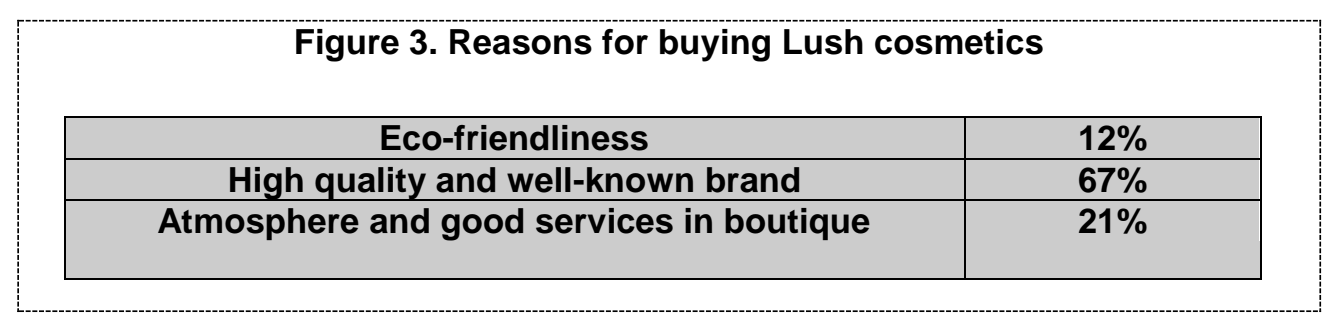

As we can see, only $12 \%$ of the respondents chose the "eco-friendly" motive as the key reason for the buying of Lush products. The majority of respondents chose the high quality and wellknown nature of the brand as the central motive. Today, eco-friendliness is still not a substantial motivation for consumption.

The next global tendency is running for discounts. Groupon and Biglion, main discount services in Russia, have a 70\% market share of collective buying services. In 2010 when these services first appeared in Russia, people were hungry for discounts and they started to use these offers intensely. But now, two years later, there is a lot of negative feedback about the poor quality of services from Groupon and Biglion. 
Healthy life style is one more global trend getting stronger worldwide. A growing numbers of people want to consume health products. For example, during last 10 years, the consumption of green tea has been increasing in Russia. According to TNS Russia, $48 \%$ of Russians drink green tea, and $24 \%$ from them are loyal consumers.

TNS Russia also conducted research about vodka, beer and cigarettes consumption in Russia. According to the research in 2011, less people are currently drinking vodka, beer and smoking in comparison with 2000. The share of vodka's consumers has decreased, as has the share of people drinking beer. As for cigarettes, thanks to a flood of public social announcements, many Russians have been giving up from smoking.

. Figure 4. Share of consumers buying the "unhealthy" products in Russia
(Source: TNS Russia, www.tns-global.ru)
\begin{tabular}{|c|c|}
\hline Share of vodka's consumers \\
\hline 2000 & 2011 \\
\hline $64 \%$ & $43 \%$ \\
\hline 2000 & 2011 \\
\hline $67 \%$ & $49 \%$ \\
\hline 2000 & Share of beer's consumers \\
\hline $39 \%$ & 2011 \\
\hline
\end{tabular}

As for eating out, fast-food global brands, especially McDonald's, still attract a lot of people. TNS mentioned that $30 \%$ of Russians regularly visit fast-food restaurants and these statistics have remained relatively constant during the last 10 years.

The trend as striving for individuality and stylish looks is universal and worldwide and depends on living standards in the country. People want to be, unique, to feel special and look stylish. While there are some rather good and famous Russian designers, the majority of Russian consumers prefer global brands due to their worldwide relevance.

TNS did a survey about how often Russian women can afford themselves an opportunity to buy new apparel, use skin care or perfume. The results are presented in the table.

Table 1. Share of Russian women bought at least $\mathbf{1}$ dress and using skin care and
perfume in $\mathbf{2 0 0 5}$ and $\mathbf{2 0 1 0}$
\begin{tabular}{|c|c|}
\hline Share of women bought at least 1 new dress during half year \\
\hline 2005 & 2010 \\
\hline $9 \%$ & $24 \%$ \\
\hline Share of women using skin care (at least 1 item) & 2010 \\
\hline 2005 & $43 \%$ \\
\hline $16 \%$ & 2010 \\
\hline 2005 & $81 \%$ \\
\hline $64 \%$ & (Share of women using perfume \\
\hline \multicolumn{2}{|c|}{ (Sww.tns-global.ru) } \\
\hline
\end{tabular}

As we can see from the table the situation with the frequency of buying something new has been getting better. Also, more Russian women have been using skin care (at least 1 item) and perfume in comparison with 2005. There can be two explanations for these figures: 1 ) income levels 
have grown, 2) the role of advertisement has increased. It is believed that Russian women are susceptible to emotional advertising about skin care and perfume.

Russian female consumers are not given to economize on cosmetics and are ready to spend money on beauty (Gerasimenko V., Hizhina A. 2012).

It's important to mention the factors affecting the decisions of why Russian women buy cosmetics:

Table 2. Factors affecting on decisions about buying cosmetics for Russian women
\begin{tabular}{|c|c|}
\hline Factor affecting on decisions about buying cosmetics & $\%$ of respondents \\
\hline Friends recommendations & $62 \%$ \\
\hline Brand's promise & $58 \%$ \\
\hline "Favorite" brand & $49 \%$ \\
\hline Price & $49 \%$ \\
\hline Publications in magazines & $48 \%$ \\
\hline Opinion of partner & $30 \%$ \\
\hline Free samples & $29 \%$ \\
\hline Internet & $25 \%$ \\
\hline Advertisement & $24 \%$ \\
\hline
\end{tabular}

(Source: $w w w .4 p . r u)$

Friends' recommendations or word of mouth are key factor influencing a women's decision to buy a particular cosmetic brand.

The next tendency we would like to stress is "purple cow" trend. The non-academic term as a "purple cow" was offered by an American entrepreneur Seth Godin (2005).

Seth Godin suggested one more "P" - Purple Cow as something phenomenal, exciting and truly noticeable. "Cows, after you've seen them for a while, are boring. They may be perfect cows, attractive cows, cows with great personalities, cows lit by beautiful light, but they're still boring" (2005).

Cows in real life are products on the shelves in shops. Every day, consumers come face to face with a lot of products which seem, for them, the same. Needless to say, today consumers are tired of advertisements, promos, discounts and have become more sophisticated in their choices. That is why it's very important to create something truly noticeable.

Lush (an English producer of cosmetics) is a good example of Purple Cow in action. The soaps look like cheese or confectionery, can be sliced and is packed in paper. What's more, all soaps have interesting unusual names (Demon in the Dark, Summer Pudding, Bohemian, Godmother and etc.).

A Russian example of Purple Cow in action is the black toothpaste with charcoal. Black is an unusual color for toothpaste and attracts the attention of innovators and people who want to be unique.

The last trend deals with the strong role of young consumers. Recently the segment of young consumers, aged around 17-23 years old, is getting stronger worldwide.

For example, in Japan the most loyal consumers for LV bags are girls around 17-21 years old. "When Japanese students graduate from a school they realize that to meet the standards of the group is extremely important and this fact affects on the consumer behavior. For example, if the members of the group possess a Louis Vuitton item but you don't it will be hard for you to find a single friend inside this group“ (Maria Eugenia Giron, 2010). 
In Moscow, the role of young consumers cannot be ignored any longer. To study this segment we surveyed the students of the Economic Department of Lomonosov Moscow State University. 102 young respondents took part in the survey.

What we found was that in order to capture young people's attention, a brand must be easily recognizable. When students were asked about their motives for the buying this or that brand they answered that their friends should notice the brand they wear. The item should display a clear logo or have a characteristic design which can be identified by a group of young people.

The students were asked to name brand № 1 for them. They named the following brands: the 2 top brands, running neck and neck, were Emporio Armani and LV, then, there was a drop off with Burberry, Gucci, Hermes, Chloe and even Shanghai Tang.

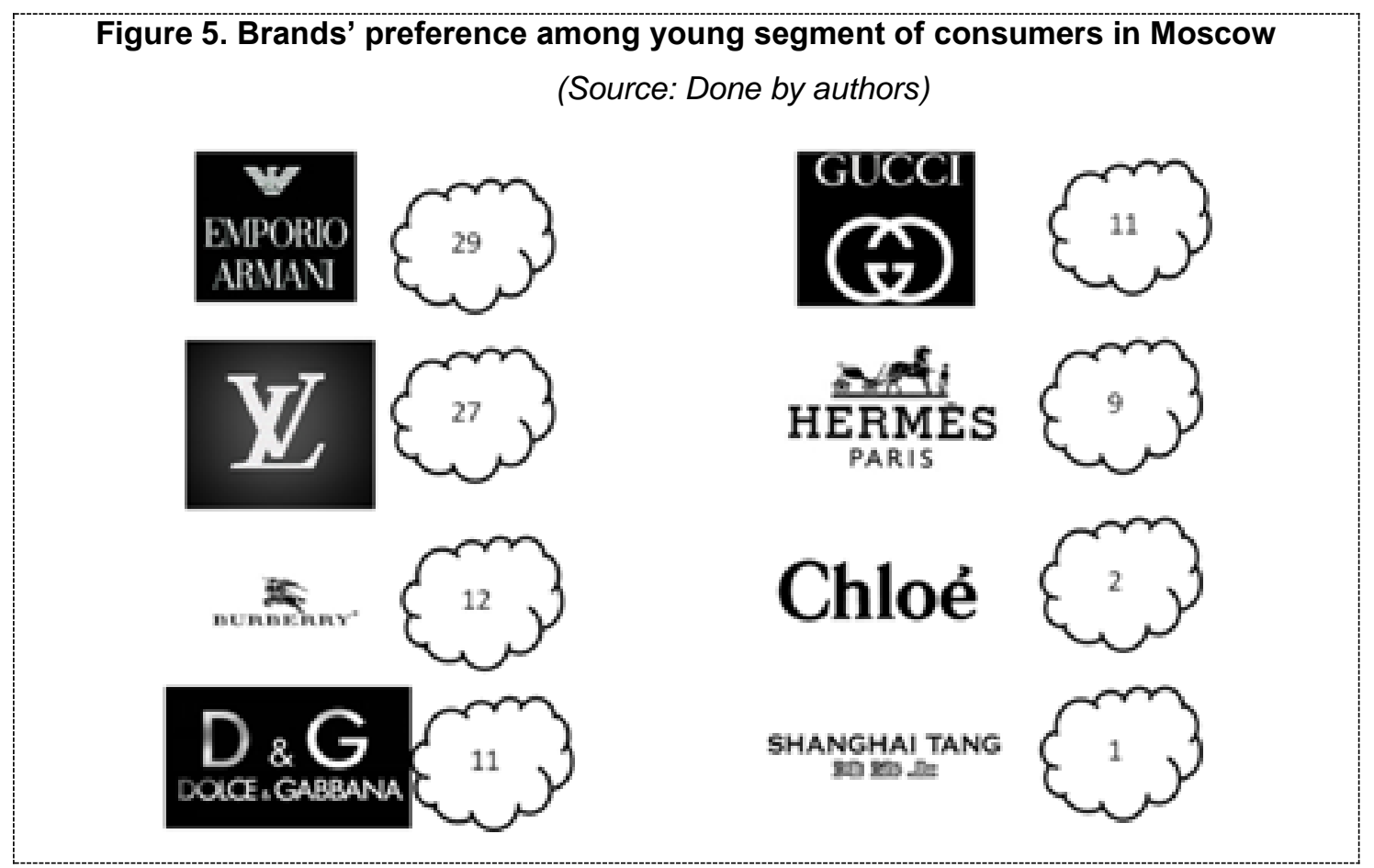

So, as we can see that young people are very educated in luxury brands and they know many global brands.

Potentially due to a limited income but desire for luxury, we can notice the recent trend where young people easily combine luxury brands with masstige and even mass market clothing.

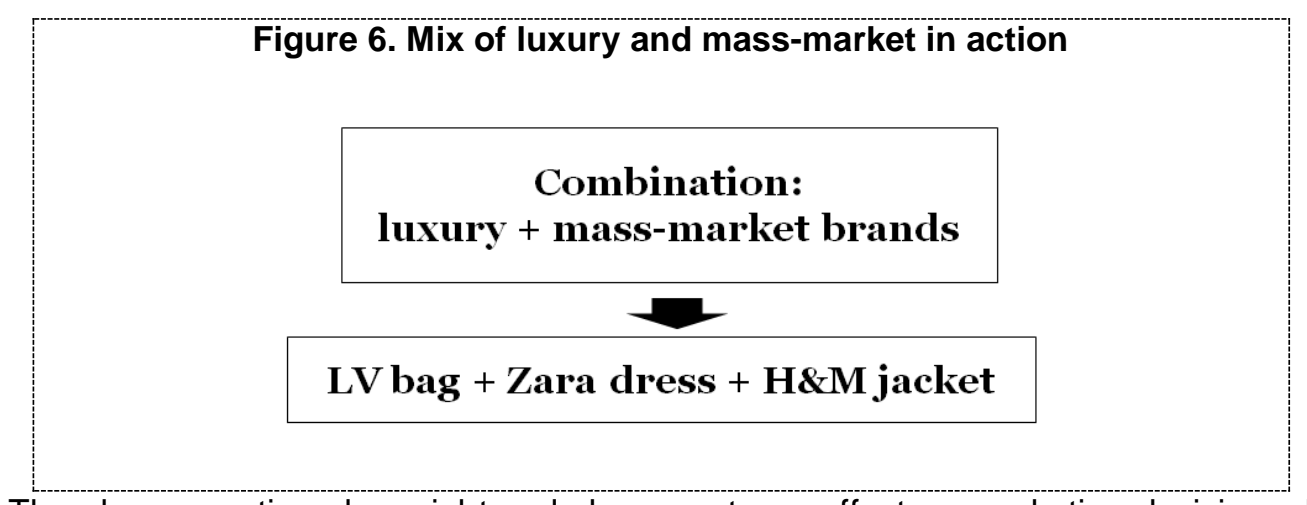

The above mentioned crucial trends have a strong effect on marketing decisions. Marketers cannot ignore these tendencies. Although Russia has been open to the world since the beginning of the 1990s, there are a lot of multinational brands still entering into Russian market every year. 
For example, the American fast-food restaurant Wendy's came into the Russian market in June 2011, and Victoria's Secret finally opened its boutiques in Moscow in September 2011. To understand what specific factors affect the Russian consumers' decisions about brands, choosing and remaining loyalty is very important for both global and local companies.

\section{Factors affecting on brands' perception in Russia}

In this paper we consider the term "brand" from the Kapferer's position as a "name with the power to influence the market" (2008). Brand has both associations in a consumers' mind and a set of special elements or tools creating and supporting these associations. Associations with the brand are connected with the perceived quality.

Further, we will analyze some signals about highly perceived quality influencing the process of consumption in Russia. The research was done for consumers in Moscow.

As we wrote before, it's very important that consumers believe in the high quality of a product or service. It's not enough to produce a good product. A good example is when the actual quality was not enough is the Bic perfume for 5 dollars.

Some years ago, Bic, the producer of cheap stationary, lighters, razors, decided to present perfume on the market. The actual quality of this perfume was high according to experts' opinions, but this product cost only around 5 dollars, which was an unbelievable price for perfume of high quality. As a result, people refused to believe in the perfume and didn't buy it, and the company suffered great losses and had to stop production.

For many customers, a low price has strong associations with poor quality. In some cases a high, but reasonable price can support perceived quality. But at the same time, according to AC Nielsen research, Russians are sensitive to discounts and promos.

One of the ways for strengthening perceived quality can be patents, awards or recommendations about the products or services. Recommendations can be from prestigious organizations with good reputations (for example, Research Centers), and also from the satisfied customers (word of mouth). For example, P\&G skin care brand Olay is recommended by the National alliance of cosmetologists.

The next way for strengthening quality is a company's age. The older the company, the longer history it has, the better. For example, the oldest Russian bank Sberbank was founded in 1841 . So many Russian people consider the Sberbank very reliable because it has existed during Tsarism, Soviet era and current days. $60 \%$ Russians think that Sberbank is the most reliable bank (according to the on-line survey). But anyway, people worldwide appreciate brands with long history and heritage. So that is why it's very important to stress the brand's age in the different marketing communications.

The country of origin strongly affects on the high perceived quality support. "Made in Europe" has powerful influence on the Russian consumers' minds. Clothes which made in Italy is considered fashionable and of high quality. Perfume and wine from France are believed to be one of the best. 
Working on this paper we conducted the survey about global vs. local brands preferences. 200 respondents took part in the survey. During the survey the respondents were asked two questions about their preferences:

1) What fashionable brands do they prefer - global or local?

2) What food brands do they prefer - foreign or Russian?

Despite being aware of fashionable Russian brands (for example, Russian designers as Valentin Udashkin, Slava Zaitsev, Alexander Terekhov) the majority (82\%) prefer global brands due to their worldwide awareness and higher perceived quality. Knowing this aspect many Russian producers prefer to use European names for clothing and shoes produced in Russia. The shoes with the Italian name Carlo Pazolini are produced in Russia, but have positioning as "Made in Italy".

As for food $73 \%$ of respondents trust more the local brands than foreign. Food brands should be done locally in many positions - vegetables, sausages, cereals and even chocolates. The survey showed that majority of respondents $(81 \%)$ prefer the Russian chocolate.

The next way for strengthening perceived quality is a connection with famous people. If a famous and respected person has some connection with the product it can strengthen its perceived quality. For example, the wife of the first USSR President Gorbachev, appreciated the perfume Guerlain. The first lady was an intellectual woman with good taste and for many soviet women she was a real example of high cultural level. She is not alive now, but people still remember her and even the perfume she used.

It is crucial to choose the appropriate person as a brand's ambassador. Strong brand should have a strong ambassador. As we wrote above, the multinational brand LV is appreciated by young consumers in many countries (Japan, China, Russia and etc.). So a brand's communications department should take into account the specific of this young audience and present a brand ambassador relevant to them.

Young people like stories of success, about people who had to struggle and triumphed. For example, such LV brand's ambassadors as Gorbachev, Denev and even Angelina do not work for the young people.

The above-mentioned personalities are great achievers but a bit old-fashioned for the young people because they are from the other epoch.

Young people dream to change the world and want to see somebody rebellious, more brutal and challenging. We did the survey about heroes for the young people. They are excited about great innovators such as Steve Jobs or Bill Gates, people who change the world, or a person, even fictional, who saves the world (somebody brave like Agent 007) and courageous race car drivers such as Fernando Alonso. A marketer of a brand should consider a specific brand ambassador to catch their young audience's attention. The brand ambassador should be relevant to the individualities of young people (Ochkovskaya M., 2012).

One more way for strengthening perceived quality is an accent on the hand-made process. "Hand-made" is good for, among many, chocolates, clothes, cosmetics and toys. For example, Lush, an English fresh hand-made cosmetics company, always stresses that all their products are made by hand and it allows them to justify higher pricing. 
Speaking about perceived quality, it's important to mention the situation with knock-offs (fake or copied products). Knock-offs is a global problem for famous brands worldwide and they negatively affect a brands' reputation.

We studied the Russian attitude to knock-offs among young and adult consumers. According to the survey, young people have a negative attitude towards knock-offs, but as for adults their attitude to these replicas is rather neutral and they even consider it rather reasonable to buy a knock-off if it has the appropriate quality.

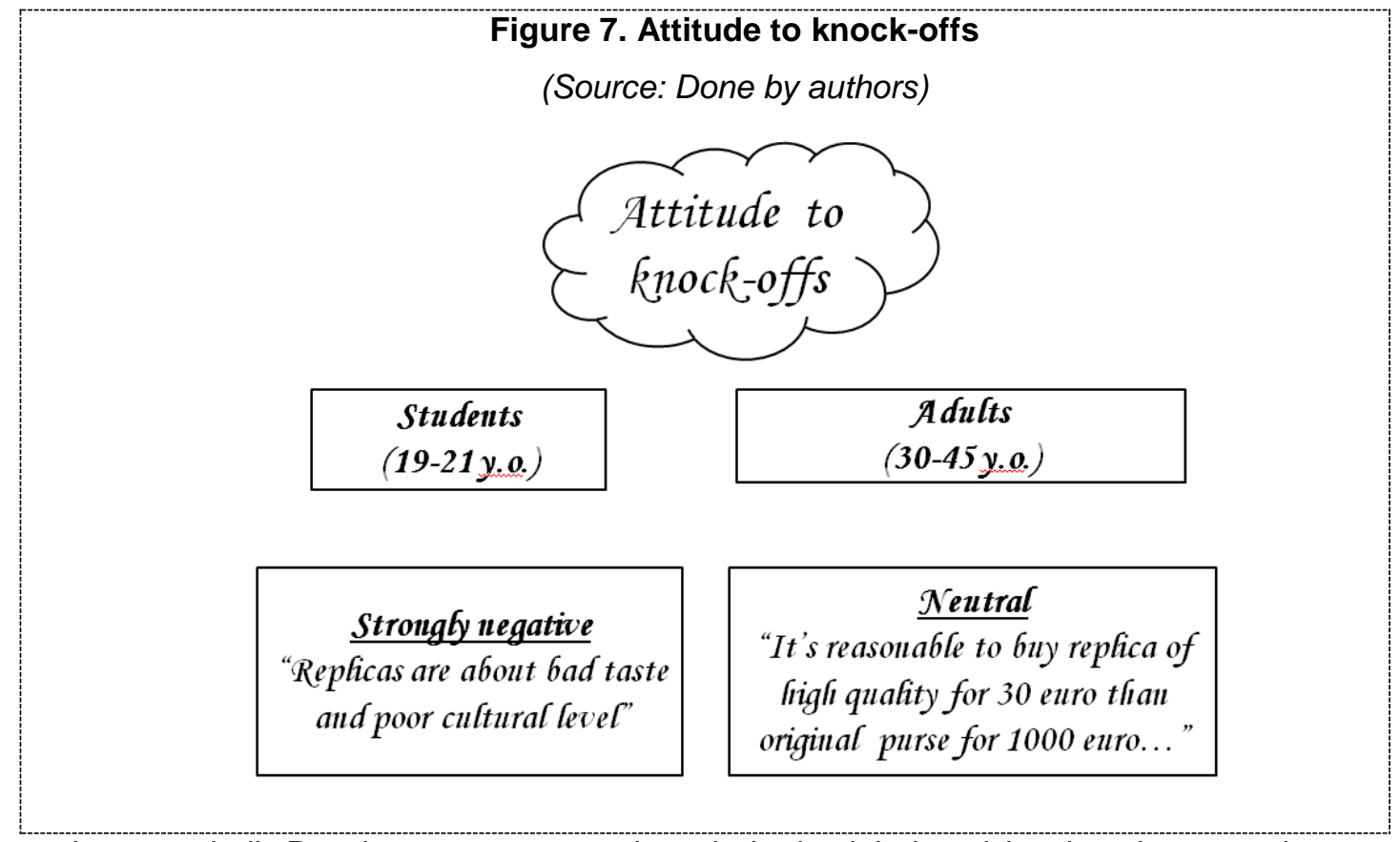

In a nutshell, Russians are open to brands both global and local and are ready to spend money. The brands should be believed to have high perceived quality and the marketers should take into account the above-mentioned tips to catch the Russian customers.

\section{Limitations and further research}

Although the present research was not formally hypothesized, it allowed to demonstrate that global trends affecting consumer behavior have specific implementation in Russia. We also analyzed the ways for the product's perceived quality support in Russian context using interview and survey methods.

There are some limitations about marketing research in Russian context. In Russia many people are not sure about their expectations about a product or service. And the customers rarely tell the truth and provide the new information. That is why the marketing research results should be taken into account carefully. But anyway it is needed to study Russian consumers to understand their needs. The conducted research was more descriptive and samples of respondents were rather small around 100 people.

Russia is a huge and versatile country. It's a country of diversity and extremities. There are very different levels of income, diverse cultures, nationalities, traditions and languages, various climate zones. We concentrated our research on Moscow. Needless to say, Russian capital, Moscow, differs very much from the other regions. 
Further we are going to study marketing trends in Russian regions and compare them with Moscow ones. So to conduct business in various regions it's necessary to carry out the specific marketing research in the area. As Sir Martin Sorrel Chief, executive of the WPP, a world leader in marketing communications services said (meaning Russia): "It is not an easy market to operate in... You need a lot of local knowledge".

\section{Bibliography}

1) Aaker D. "Building strong brands". - Free Press Business, 2002.

2) Aaker D. "Managing brand equity: capitalizing on the value of a brand name". - The Free Press, 1991.

3) Aaker D. "Marketing research". - John Wiley \& Sons, 2001.

4) Aaker D. "Brand relevance: making competitors irrelevant". - John Wiley \& Sons, 2011.

5) Aaker D. "Brand portfolio strategy: creating relevance, differentiation, energy, leverage and clarity". - Simon \& Schuster, 2004.

6) Gerasimenko V., Rybalko M., etc. "Marketing". - Moscow: INFRA-M, 2009.

7) Gerasimenko V., Hizhina A. "Factors affecting on consumers behavior on FMCG markets in Russia in post-crisis", Marketing Magazine №3, 2012.

8) Godin Seth. "Purple Cow: transform your business by being remarkable". - Penguin Books, 2005.

9) Harvard Business Review on Brand Management. Aug 25, 1999.

10) Heine Klaus. The concept of luxury brands. www.conceptofluxurybrands.com

11) Kapferer J.-N. "The new strategic brand management: creating and sustaining brand equity long term". - Kogan Page, 2008.

12) Kapferer J.-N. "The Luxury Strategy: Break the Rules of Marketing to Build Luxury Brands". - Kogan Page, 2009.

13) Keller K.L. "Strategic brand management: building, measuring, and managing brand equity". - Prentice Hall, 2008.

14) Kotler P., Armstrong G. "Principles of Marketing”. - Prentice Hall, 2008.

15) Maria Eugenia Giron. Inside Luxury. The growth and future of the luxury goods industry: a view from the top. - LID, 2010.

16) Ochkovskaya M. Marketing communications in luxury industry. Marketing communications magazine. №4, 2012.

17) Ogylvy David. "Ogilvy on Advertising". - PRION, 2008.

18) "The 10 Trends You Have to Watch". Harvard Business Review. July-August 2009.

19) www.acnielsen.ru

20) www.gks.ru

21) www.tns-global.ru

22) www.trendwatching.com 